IECHITCAL INFORMATION OIN BUILDING MATERIALS

TIBM - 28

FOR USE IN THE DESIGN OF LOT-COST HOUSING

TTE MTAIOMAL RTRPAU OF STANDARDS

UIITED STATES DEPARTMENT OF COMMERCE

TASEITGTOIN, D. C.

August 6,1936

\title{
PAINTING OF FERROUS METALS
}

The principal advantege of painting iron or steel parts of a house is to afford notection against corrosion. Fowever, the decorative effect is of increasing imoortance with the widening use of steel for builing purposes, Bare steel surfaces, as well as tin or terne-coated metal, should be nainted without delay after installation.

Galvanized surfaces should not be painted for at least six months after instailation. Teathering roughens a galvanized surface, greatly improving the adlerence of the paint. If, however, it is necessary to paint such surfaces before they have been allowed to weather, they may be treated mith an etching soluiion. Several of these, as well as a number of raints for vse on various netals, are described in National Bureau of Siandards Letter Circular 422 , "The Painting of Structural Metal (Steel, Galvanized Metal, Tin Plate and Copper)", (August 10, 1934), 1 by Percy H. Talker and E. F. Hickson.

Before being painted, a metal surface should be freed from scale, oily or Ereasy films or rust, and should be dry. Oil or grease is removed by a solvent such as gasoline or benzene; scale and rust by a wire scratch brush or a sand blast. Painting should be done on a clear warm day; never in wet or foggy weather. The paint may be applied by brusining or by spraying.

Paints consist of a liquid portion called the "vehicle" and a solid portion known as the "pigment". The vehicle contains a nonvolatile portion consisting of drying oils such as linseed, fish, tung, etc., resins and comounds of drying metals, as well as volatile thinner, such as mineral spirits, turpentine, etc. The pigment consists of very finel divided solid matter that is essentially insoluble in the vehicle. Many paint technologists recommend that the pigment in

(Tree).

Available from the National Bureau of Standard.s, Washington, D. C. 

a dried paint film s'rould be at least 28 percent by volume. Among the important piements for paints to be used on metals are red lead, basic lead chromate, iron oxide, white lead, zinc oxide, various carbon pigments, aluninum powder, etc. Under conditions favorable to corrosion of the basis metal, such as bare spots, breals in the coating, etc., some pigments, such as carhon black, increase corrosion of the metal if in direct contact with it. Other pigments, such as basic lead chromate, retard corrosion under sinilar circumstances. It is important, therefore, in primine or first coats, to avoid the use of paints containing carbon black, although tis is often an excellent Digment in a finish paint coat.

The "covering" or liding power of a paint is largely determined by the specific properties and particle size of the pigment material. In general, the firer the particle size, the greater the covering power. Other inportant qualities of the pigment are color-permanence and inertness to attack by the atmosphere. The deteriorating effect of sunlight on the vehicle of paints mav be minimized by the use of dark pigments Which tend to exclude the larmful radiation. Aluminum paint is considered very good from this stendpoint because the aluminum pigment consists of particles having the forn of small thin scales which, by "leafing out" in the liquid vehicle, overlap and form a layer which efficiently exclujes harmful light rays. Aluminum paint is also considered relatirely effective in excluding water from the metal surface to which it is apolied.

In nearly every case, at least two coats should be used in painting the metal parts of a house. The first or "primingll coat on bare iron or steel should be a paint containing inhibitive pigments, and should cover the netal completely. It should be free from pores or blisters, and should adhere well to the metal surface. After the first coat has completely dried, the finishing paint should be applied in one or nore coats as needed. Fach coat should be allowed. to dry thorouging before the next is applied. More than two finish coats are not ordinarily required. It is important to avoid building up paint films to an excessive thiciness because of the trouble which may result from scaling.

Some methods of painting metals to be buried in the soil are suggested in TIBM - 29, "Corrosion of Ferrous Metals Underground." 
